Ахманова, О. С. Словарь лингвистических терминов. Изд. 4-е. Москва : КомКнига, 2007. 576 c. (Akhmanova, O. S. Slovar' lingvisticheskikh terminov. Izd. Chetvortoy. Moskva: KomKniga, 2007. 576 s.) Print.

Ковалевська, Т. І. Інтонаційніі засоби актуалізації емоційного висловлювання. Науковий часопис Національного педагогічного університету імені М.П. Драгоманова. Серія 9. Сучасні тенденції розвитку мов. № 5, 2011. C. 140-143. (Kovalevskaya, T. I. (2011). Intonatsiynii sredstva aktualizatsii emotsional'nogo vyrazheniya. Nauchnyy zhurnal Natsional'nogo pedagogicheskogo universiteta imeni M.P. Dragomanova. Seriya 9. Sovremennyye tendentsii razvitiya yazykov. № 5 . S. 140-143).

Теоретична фонетика англійської мови : навч. посіб. для студентів факультетів іноземних мов. // Проект / Колектив авт.: Колесник, О. С., Гаращук Л. А., Гаращук К. В. Житомир : Вид-во ЖДУ імені Івана Франка, 2015. 226 с. (Teoreticheskaya fonetika angliyskogo yazyka: ucheb. posobiye. dlya studentov fakul'tetov inostrannykh yazykov (2015) // / Kolektyv avt. Kolesnik, A. S., Garashchuk L. A., Garashchuk K. V. Zhitomir: Izd-vo ZHDU imeni Ivana Franko) .

Корунець, І. В. Порівняльна типологія англійської та української мов : навч. посіб. Вінниця : «Нова книга», 2004. 464 с. (Korunets', I. V. (2004). Sravnitel'naya tipologiya angliyskogo i ukrainskogo yazykov: ucheb. posobiye. Vinnitsa: «Novaya kniga»).

Паращук, В. Ю. Теоретична фонетика англійської мови : навч. посіб. для студ. фр-тів ін. мов. Вінниця : НОВА КНИГА, 2009. 232 c. (Parashchuk, V. Y. (2009). Teoreticheskaya fonetika angliyskogo yazyka: ucheb. posobiye. dlya stud. f-tov dr. yazykov. Vinnitsa: NOVAYA KNIGA).

Соколова, М. А. Теоретическая фонетика английского языка : учеб. для студ. высш. учеб. заведений. Изд 3-е. М. : ВЛАДОС, 2004. 286 c. (Sokolova, M. A. (2004). Teoreticheskaya fonetika angliyskogo yazyka: ucheb. dlya stud. vyssh. ucheb. zavedeniy. Izd 3-ye. M.: VLADOS).

\title{
A COMPLEX OF EXERCISES TO DEVELOP ENGLISH PROSODIC SKILLS IN SPEAKING IN HIGH SCHOOL STUDENTS
}

\section{Ponomarova, A. Sikorska \\ Abstract}

Background: The importance of mastering good pronunciation is undeniable. According to the current curricular for secondary schools, high school students have to produce phonetically correct speech. The purpose of studying phonetics is to shape the standard phonetic image of the phonemes and intonation patterns and make use of them in speech. The observation of the educational process shows that the level of prosodic competence of high school students in Ukraine is quite low, the special exercises and tasks for improving the pronunciation skills in textbooks are almost not presented.

Purpose: The objective of this paper is to develop a complex of exercises to teach prosody and intonation at high school. The authors examine the differences between English and Ukrainian prosodic constituents, and on the basis of this analysis suggests the ways to master each component in the developed tasks.

Results and Discussion: By focusing on certain differences between the prosodic systems of the English and Ukrainian languages the study presented in the article has provided possible ways to improve the prosodic skills of high school students. The further perspective of the study relates to developing, expanding, piloting and modifying tasks and exercises for mastering prosody.

Keywords: mastering prosody, intonation, prosodic competence of students, prosodic component of English language, senior pupils, prosodic component of pronunciation quality.

\section{Vitae}

Vira Ponomarova, PhD, Associate Professor of the Department of Teaching Methodology of Ukrainian and Foreign Languages and Literatures.

Her research interests include learning strategies, phonetics and prosody, andrology, language testing and assessment (LTA), teaching and material design of English for cross cultural communication.

Correspondence: 4091859@ukr.net

Alyona Sikorska, master student of the Department of Teaching Methodology of Ukrainian and Foreign Languages and Literatures. Her research interests include learning intonation and prosody of foreign languages, prosodic interference. 
УДК $=371: 811$

ORCID: 0000-0001-7148-4805

\title{
ПІДХОДИ І ПРИНЦИПИ ФОРМУВАННЯ У МАЙБУТНІХ ФІЛОЛОГІВ ЛІНГВОСОЦІОКУЛЬТУРНОЇ КОМПЕТЕНТНОСТІ В ЧИТАННІ ЗАСОБАМИ ПОЕТИЧНОГО ТВОРУ
}

\begin{abstract}
У статmі на основі наукової літератури визначено і детально проаналізовано підходи і принципи формування у майбутніх фрілологів лінгвосоціокультурної компетентності в читанні засобами поетичного твору. В результаті дослідження було обгрунтовано, що теоретичну основу формування лінгвосоціокультурної компетентності в читанні складають компетентнісний, герменевтичний, комунікативний та лінгвокраїнознавчий підходи, які інтегруються у процесі навчання.

Ключові слова: лінгвосоціокультурна компетентність (ЛСКК), принцип навчання читання, інтерпретація, культурно-специфічні поняття, поетичний твір, мовні засоби.
\end{abstract}

Постановка проблеми та актуальність дослідження. Формування лінгвосоціокультурної компетентності відіграє важливу роль у підготовці майбутніх фрілологів, адже вона забезпечує здатність студентів до усвідомлення явищ інших культур та до здійснення міжкультурної комунікації. Автентичні тексти є зразками реальної комунікації, а поетичний твір - важливою складовою культурного потенціалу. Культурна картина світу, будучи поглядом члена культури на зовнішній світ, є сукупністю знань і уявлень про цінності, норми, мораль, менталітет власної культури і культур інших народів. Ці знання і уявлення про світ, трансфрормуючись у художні образи, можуть вступати в найрізноманітніші відношення зі світом. Поезія - вища форма буття національної мови. У поетичній творчості з найбільшою повнотою і сконцентрованістю виражається дух народу - своєрідність його історичного та культурного розвитку, його психічного ладу. Зрозуміти поезію іншого народу - означає зрозуміти інший національний характер, емоційний світ іншої культури. Таким чином, поетичний твір є культурним френоменом і фррагментом мовної картини світу, у якому відображаються культура, історія, цінності, норми, мораль, ідеали, психологія народу (Diaz-Rico, Weed, 2002).

Аналіз останніх досліджень. Дослідження методичної літератури показало, що проблема формування лінгвосоціокультурної компетентності зокрема в читанні $є$ досить актуальною. Питанню визначення підходів і принципів формування лінгвосоціокультурної компетентності В читанні присвячені дослідження О.В.Би- рюк, В.В.Сафонової, О.О.Коломінової, В. М. Топалової, Л. П. Рудакової, Н. Я. Бачинської, Т.В.Починок, О.В.Бирюк, Т.П.Дружченко, М. Бірам (М. Byram), І. Серку (І. Sercu), Д. Люсьє (D. Lussier) та інших. Також, значну увагу науковців приділено засобам формування лінгвосоціокультурної компетентності, серед яких іншомовні тексти різних жанрів: вірші, оповідання, прислів'я, пісні, аудіотексти, про що свідчать праці О. В. Бирюк, І. О. Ісенко, С. Е. Кіржнер, В. Є. Лапіної, В. С. Пащук, І. В. Тєрєхової, Т. О. Яхнюк. Проаналізувавши низку праць як фундаторів теорії експерименту, так і останні теоретичні дослідження підходів і принципів формування формування лінгвосоціокультурної компетентності в читанні робимо висновок, що в усіх дослідженнях були висвітлені лише окремі теоретичні аспекти даної проблематики, а особливості реалізації підходів і принципів формування лінгвосоціокультурної компетентності в читанні засобами поетичного твору залишено поза увагою науковців.

Мета статті. Враховуючи актуальність проблеми та недостатній рівень ії дослідженості, ставимо за мету цієї статті визначити та детально проаналізувати підходи і принципи формування лінгвосоціокультурної компетентності в читанні засобами поетичного твору.

Виклад основного матеріалу. Методичні засади формування у майбутніх фрілологів лінгвосоціокультурної компетентності в читанні засобами поетичного твору полягають у визначенні в першу чергу підходів і принципів. Підхід - це ідеологія і методологія вирішення 
проблеми, яка розкриває основну ідею, соціально-економічні, фрілософські, психолого-педагогічні передумови, головні цілі, принципи, етапи, механізми досягнення цілей (Ibrahimov, 2007). Підхід є ключовою категорією методики. Він задає основну траєкторію вибору цілей і змісту, методів, засобів, прийомів, організаційних фоом навчання. Розуміючи підхід (за І. Зимньою) як глобальну і системну організацію та самоорганізацію освітнього процесу, яка охоплює всі його компоненти і насамперед самих суб'єктів педагогічної взаємодії викладача і студента, вважаємо, що сучасна методична наука орієнтована на інтегрування різних підходів до навчання іноземної мови, адже навчальний процес $є$ багатогранним, охоплює природу мови та мовленнєвої діяльності, культурного контексту існування мови, особистісних характеристик суб'єктів навчання, співвідношення процесу навчання мови з іншими дисциплінами в контексті цілісної освітньої концепції. Жоден підхід не здатний вибудувати систему навчання так, щоб були враховані об'єктивні (мова, мовлення, навчальний процес) та суб'єктивні (особистісні) чинники.

Проаналізувавши різні джерела, присвячені описові підходів до навчання іноземної мови, а також врахувавши предмет нашого дослідження - підходи і принципи формування у майбутніх фрілологів лінгвосоціокультурної компетентності в читанні засобами поетичного твору - ключовими визначаємо такі підходи: компетентнісний, герменевтичний, комунікативний, лінгвокраїнознавчий.

Методологічною основою сучасної освіти, в тому числі вищої професійної, $є$ компетентнісний підхід, що визначено в багатьох сучасних джерелах і нормативних документах (Petrov, 2005). Означений підхід передбачає розроблення системи забезпечення якості підготовки майбутніх фрахівців, яка відповідає потребам сучасного ринку праці (Nalitkina, 2009). Ключовим поняттям у компетентнісному підході $є$ компетентність, яку розуміємо (за О. Петровим) як інтегративну якість особистості, яка сорормована на основі знань, навичок та вмінь, індивідуально-психологічних якостей, а також практичного досвіду, що виявляються в здатності та готовності людини до практичних дій, вирішення практичних проблем (Petrov, 2005). Формування у майбутніх фрілологів лінгвосоціокультурної ком- петентності в читанні засобами поетичного твору передбачає набуття студентами лінгвосоціокультурних знань, відповідних навичок та вмінь, а також здатності та готовності читати та інтерпретувати лінгвосоціокультурну інфрормацію в автентичних текстах.

Поділяючи висновки Т. Плетяго про те, що читацька компетентність студента є інтегральною характеристикою особистісних якостей, сукупністю знань і умінь, що визначають готовність і здатність до актуалізації та збагачення особистісного і професійного досвіду в процесі сприйняття, інтерпретації, розуміння і особистісного осмислення тексту на основі володіння стратегіями ефективного пошуку, відбору і організації інформації; оперування різними соціокультурними кодами (Pletiago, 2012), кінцевою метою формування лінгвосоціокультурної компетентності в читанні вважаємо сорормованого компетентного читача, який володіє лінгвосоцікультурними знаннями, навичками та вміннями, а також здатен переносити їх у площину читання та інтерпретації поетичних інших творів того історико-культурного періоду, в межах якого відбувалося навчання; здатний та готовий набувати нових лінгвосоціокультурних знань, розвивати лінгвосоціокультурні вміння під час читання.

Ґрунтуючись на рівнях читацької компетентності - вербально-семантичному, когнітивному, прагматичному (Pletiago, 2012), визначаємо, що компетентний читач (на вербально-семантичному рівні) здатен і готовий набувати нових лексичних одиниць 3 денотативним та конотативним маркерами семантики (нових культурно маркованих сем відомих лексичних одиниць), а також застосовувати ці лексичні одиниці під час рецепції речень; на когнітивному рівні читач здатен інтерпретувати та розуміти фрактуальну, концептуальну, підтекстову та емотивно-оцінну лінгвосоціокультурну інфрормацію на рівні тексту (змістово-смислових фррагментів тексту); на прагматичному рівні - успішно виконувати читацьку діяльність, орієнтовану на самовдосконалення, саморозвиток, на збагачення професійних лінгвосоцікультурних знань на вмінь.

Компетентнісний підхід передбачає дотримання принципів (системи вихідних теоретичних положень, керівних ідей і основних вимог до проектування цілісного освітнього процесу, що випливають з встановлених пси- 
холого-педагогічною наукою закономірностей і досліджуваних в цілях, змісті, педагогічній технології, діяльності викладачів і діяльності студентів), серед основних принципів формування ЛСКК в читанні виділяємо (Matushanskii, 2009):

- принцип професійної зорієнтованості (врахування програмних вимог до читання та лінгвосоціокультурної компетентності майбутніх фрілологів, особливості профресії фрілолога): орієнтований на формування компетентного читача, здатного розуміти та інтерпретувати різножанрові твори;

- принцип розвитку креативності студентів (передбачає максимальну орієнтацію на творче начало у навчальній діяльності студентів; спрямований на формування потреби в творчості і умінь творчості): процес інтерпретації поетичного твору $є$ творчим, допускає варіативність; лінгвосоціокультурна компетентність майбутнього фрілолога вимірюється глибиною аналізу художнього твору, здатністю аналізувати та синтезувати різноманітну інформацію в новий мисленнєвий продукт;

- принцип безперервного навчання: формування лінгвосоціокультурної компетентності орієнтоване на те, щоб сорормувати стратегії розуміння та інтерпретації ЛСКК під час читання, а також здатність і готовність застосовувати ці стратегії під час читання та аналізу інших поетичних творів.

Герменевтичний підхід до навчання читання спрямований насамперед на подолання лакун міжкультурного спілкування в умовах рецептивного білінгвізму, міжмовної інтерференції, що зумовлені мовними та екстралінгвістичними фракторами; на формування в студентів уявлень про культурно-специфічні поняття та реалії, які не мають аналогів в україномовній свідомості, незнання яких перешкоджає адекватному розумінню автентичного тексту (Shovkovyi, 2011). Герменевтичний підхід орієнтований на інтерпретацію текстів: метою навчання в межах цього підходу є формування інтерпретаційних умінь (тобто давати тлумачення окремим лексичним одиницям, граматичним конструкціям, змістовим одиницям тексту та смислу тексту), яке здійснюється шляхом вправляння в інтерпретації мовних одиниць та позамовних фактів, які містяться в тексті.
Ключовими принципами герменевтичного підходу є співвивчення мови і культури, домінантної ролі вправ (Shovkovyi, 2011).

Відповідно до принципу співвивчення мови і культури в межах герменевтичного підходу процес формування лінгвосоціокультурної компетентності на матеріалі поетичного твору здійснюється як вивчення культури через мовні засоби художнього твору (метафори, безеквівалентна лексика, фонова лексика, концепти, прецедентні феномени, культурні символи), водночас вивчення культурно маркованих одиниць мови є можливим тільки шляхом занурення в культурний контекст. Інтерпретація поетичного твору відбувається шляхом експлікації мовних засобів, особливо їхніх конотативних культурно маркованих сем, а також інтерпретації окремих міні-ситуацій тексту, у яких інформація виводиться на основі пресупозиційних знань.

Відповідно до принципу домінантної ролі вправ формування інтерпретаційних умінь здійснюється шляхом вправляння в аналізі та інтерпретації. Ми вбачаємо доцільність застосування лінгвосоціокультурних вправ на інтерпретацію лексичних одиниць, блоків фрактуальної, підтекстової та емотивно-оцінної інформації, інтегрування означених блоків інформації в код змісту та смислу тексту.

Комунікативний підхід орієнтований на формування комунікативних умінь шляхом вправляння в комунікації (Sharapova, 2009). Мовленнєва компетентність в читанні $€$ компонентом комунікативної компетентності, яка покликана забезпечувати обмін інформації. Читання належить до інформативного опосередкованого способу комунікації (Sharapova 2009). Відповідно до комунікативного підходу процес навчання читання (а також інтерпретації - в контексті формування лінгвосоціокультурної компетентності) має здійснюватися на основі принципів (Safonova, 1998):

- комунікативної спрямованості навчання (формування ЛСКК здійснюється у процесі вивчаючого читання автентичних поетичних текстів);

- взаємодії функції і форми мовних одиниць (лінгвокультуреми - одиниці мови з культурним маркером семантики вивчаються інтегровано: форма і зміст, за таким принципом вивчаються культурні концепти, метафори, символи, безеквівалентна та фонова лексика); 
- автентичного характеру навчальних матеріалів (поетичні твори як засіб навчання $€$ автентичними, тобто не створеними для навчальних умов, тому лінгвосоціокультурна інформація представлена у повному культурному контексті й відображає культуру та ментальність носіїв мови);

- інформаційного розриву (кожен поетичний текст повинен містити нову, не відому студентам лінгвальну та екстралінгвальну інформацію: нові соціокультурні знання країнознавчого, літературознавчого характеру, нові лексичні одиниці, нові семи відомих лексичних одиниць, нові концепти, метафори, символи тощо).

Під час навчання читання як виду мовленнєвої діяльності спираємося на принципи навчання читання (John-Steiner. 1994):

- навчання читання має бути навчанням мовленнєвої діяльності (читання тексту в навчальному процесі завжди має виступати як конкретний акт комунікації, тобто має бути направлене на його розуміння, а в тій мірі повноти і точності, яка відповідає поставленим цілям): формування ЛСКК в читанні має бути зорієнтоване на розуміння актуальної, підтекстової, концептуальної та мотивно-оцінної інформації;

- читання має бути пізнавальним процесом (тексти мають бути, з одного боку, доступні, а з іншого боку, мати певні труднощі, подолання яких активізує роботу мислення, розширює знання студентів): в лінгвосоціокультурному аспекті з поетичного твору студенти повинні одержувати нові лінгвальні (про культурно марковану семантику метафор, концептів, слів-символів), нові екстралінгвальні знання;

- тексти для читання повинні містити важливу фахову інформацію: у межах ЛСКК вказані вище знання для майбутніх фрілологів і $\epsilon$ фахово важливими, вони формують відповідну компетентність - здатність та готовність переносити накопичувальні знання в умови читання та інтерпретації інших творів;

- під час навчання читання слід спиратися на володіння мовними знаннями: в аспекті формування ЛСКК передбачається вивчення насамперед культурно маркованих лексичних одиниць, які і складають основу для інтерпретації текстів;
- навчання читання має охоплювати не тільки рецептивну, але і репродуктивну діяльність студентів: читання поетичного твору передбачає інтегроване формування скоріше не репродуктивного, а продуктивного мовлення шляхом обговорення змісту та смислу прочитаного; у продуктивному мовленні студенти використовують лінгвальні та екстралінгвальні лінгвосоціокультурні знання;

- функціонування читання як мовленнєвої діяльності вимагає автоматизації прийомів його здійснення: метою формування ЛСКК у читанні $€$ формування навичок та вмінь автоматичного сприйняття та інтерпретації лінгвосоціокультурної інформації на рівні слова, речення, надфразової єдності, тексту.

У навчанні іноземних мов застосовують кілька країнознавчих підходів - лінгвокраїнознавчий, комунікативно-етнографічний, соціокультурний (Kuzmina, Kavnatskaya, 2001). Варто відразу зауважити, що означені підходи мають багато спільних рис. Формування ЛСКК у читанні вважаємо доцільним здійснювати здійснюватися і на основі лінгвокраїнознавчого підходу, який орієнтований на навчання іноземної мови у зв'язку з культурою та історією, проникнення у світ культури, менталітету носіїв мови через мовні засоби (Rozhneva, 2004). Лінгвокраїнознавчий підхід ґрунтується на таких засадах:

- розвиток самосвідомості студента як культурно-історичного суб'єкта, носія колективних та індивідуальних соціокультурних характеристик, його ролі як суб'єкта діалогу культур, розвиток загальнокультурних і комунікативних умінь використовувати іноземну мову як засіб міжкультурного спілкування (Safonova, 1998);

- попереднє вивчення соціокультурного контексту функціонування мови в конкретній країні чи національному середовищі (Safonova, 1998): означений принцип орієнтований на створення системи пресупозиційних знань, необхідних для розуміння мови;

- головним джерелом лінгвокраїнознавчої інфрормації визначено лексику з національно-культурною семантикою, яка й імплікує країнознавчу інформацію; опис мовних одиниць здійснювався в загальному комплексі 3 вивченням уявлень певного народу про позначувані лексемами поняття (Kuzmina, Kavnatskaya, 2001); до такої лексики нами від- 
несено культурно марковану безеквівалентну та фонову лексику, метафори, символи, концепти;

- відбір і використання країнознавчих текстів (Kuzmina, Kavnatskaya, 2001); добору підлягають тексти, які містять лінгвосоціокультурну інформацію на рівні слова, речення, надфразової єдності (фрагменту тексту), цілого тексту;

- зіставлення культури іноземної мови 3 рідною (особливо в плані семантики лексичних одиниць) для виявлення спільних та відмінних рис з метою уникнення інтерференції (Kuzmina, Kavnatskaya, 2001); диференціації спільних та відмінних рис потребують лексичні одиниці з асиметрією конотативних значень в рідній та іноземній мовах, семантика слів, що позначають символи культури, образні та ціннісні семантичні прошарки концептів.

Лінгвокраїнознавчий підхід вважаємо доцільним застосовувати до читання, аналізу та інтерпретації текстів, які містять лінгвосоціокультурну інформацію, адже ані метафори, ані концепти, ані символи не використовуються мовцями абстрактно, поза текстом і контекстом, вони є частиною комунікації, інтегруються в інформаційні блоки, відіграють важливу роль в розумінні цих блоків; власне, через експлікацію названих мовних одиниць і відбувається інтегрування змістово-смислових одиниць у коди змісту та смислу.

Висновки. Отже, методичні засади формування у майбутніх фрілологів лінгвосоціокультурної компетентності в читанні засобами поетичного твору полягають у визначенні в першу чергу підходів і принципів, так як підхід є ключовою категорією методики, що задає основну траєкторію вибору цілей і змісту, методів, засобів, прийомів, організаційних фрорм навчання. В результаті дослідження було доведено, що теоретичну основу формування лінгвосоціокультурної компетентності в читанні складають компетентнісний, герменевтичний, комунікативний та лінгвокраїнознавчий підходи, кожен з яких детально проаналізовано у статті. Зазначені підходи і принципи забезпечують формування у майбутніх фрілологів лінгвосоціокультурної компетентності в читанні і можуть інтегруватися в процесі навчання.

Перспективи дослідження. Подальшими напрямками дослідження може бути виявлення критеріїв і показників сформованості лінгвосоціокультурної компетентності в читанні засобами поетичного твору, педагогічних умов, які забезпечують формування високого рівня лінгвосоціокультурної компетентності.

\section{References}

Diaz-Rico, L. T., Weed K. Z. (2002). The crosscultural, language, and academic development. - Allyn and Bacon. Boston. Print.

Ibrahimov, H.l. (2007). Kompetentnosnyi podhod $v$ professionalnom obrazovanii (Ибрагимов Г. И. Компетентностный подход в профессиональном образовании). - ОТО. №3. Print.

John-Steiner, V. (1994) Sociocultural approaches to language and literacy: An interactionist approach. - Cambridge University Press. UK. - pp. 331 - 346. Print.

Kuzmina, L. G., Kavnatskaya Ye. V. (2001). Sovremennye kulturuvedcheskiye podhody $k$ obycheniyu inostrannym yazykam (Кузьмина Л.Г., Кавнатская Е.В. Современные культуроведческие подходы к обучению иностранным язикам). Voronezhskiy vestnik. № 2. - pp. 108 - 117. Print.

Matushanskii, H. U., Kudakov O.R. (2009). Metodologicheskiye printsipy kompetentnosnogo podhoda $v$ professionalnom obrazovanii (Матушанский Г.У., Кудаков О.Р. Методологические принципы компетентностного подхода в профессиональном образовании). - KPZh. - №11-12. Print.

Nalitkina, O. V. (2009). Kompetentnostnyi podhod kak osnova novoi paradigm obrazovaniуа (Налиткина О. В. Компетентностный подход как основа новой парадигмы образования). - lzvestiya RGPU imeni A. I. Gertsena. - №94. Print.

Petrov, A. Yu. (2005). Kompetentnostnyi podhod $v$ nepreryvnoi professionalnoi podgotovke inzhenerno-pedagogicheskih kadrov (Петров А. Ю. Компетентностный подход в непрерывной профессиональной подготовке инженерно-педагогических кадров). Diss. Viatka. Print.

Pletiago, T. Yu. (2012). Formirovaniye chitatelskoi kompetentnosti studentov vuza (Плетяго Т. Ю. Формирование читательской компетентности студентов вуза). - ONV. - №4 (111). Print.

Rozhneva, Ye. M. (2004). Vzaimosviazannoe ovladeniye yazykom i kulturoi strany izychayemogo yazyka (Рожнёва Е. М. Взаимосвязанное 